\title{
Beyond sloganeering and damage control mechanism: the vicious circle of ethical transformation and value re-orientation campaigns in Nigeria
}

\begin{abstract}
Rebranding Nigeria every time a new government comes to power is becoming a permanent feature of the country's political life. Ethical transformation and value reorientation have always been the fundamental focus of governmental agencies and institutions, organizations, and non-governmental agencies due to the decay in values, ethics and morality in the society. This essay examines President Buhari administration's "change agenda" within the context of the new rebranding campaign and how monotonous such has become in the polity over the years. It attests to the fact that successive occupants of political offices in Nigeria, particularly since the $80 \mathrm{~s}$, have never been dialectical in thoughts and action, and thus, their campaigns have suffered from the limitations of superficial bourgeois solutions to deeply structural social problems. Beyond what now appears to be mere campaign sloganeering or conscientious/desperate attempt at redeeming the image of a government that is fast losing its popularity among the citizens, this essay contends that there is the need for a radical development strategy that guarantees inclusiveness as opposed to exclusiveness in governance and that is people-driven from conception to implementation.
\end{abstract}

Volume 2 Issue 2 - 2018

\section{Mike Omilusi}

Department of Political Science, Ekiti State University, Nigeria

Correspondence: Mike Omilusi, Department of Politica Science, Ekiti State University, Nigeria, Email watermike2003@yahoo.co.uk

Received: December II, 2017 | Published: March 12, 2018

Keywords: Transformation, Orientation, Campaign, Value, Sloganeering

\section{Introduction and statement of the problem}

Nigeria is one of the most populous countries in the world, with a population of more than 160 million. The nation is immensely blessed with abundant human and material resources. The worrisome truth is that Nigeria, though a sovereign independent nation, is encumbered by a multiplicity of problems that has slowed down her advancement over the years. Some of these problems, unfortunately, are selfinflicted and flow from a morbid, deviant inclination of the politicians to unjustly and blindly engage in self-enrichment and general corruption. ${ }^{1}$ It has great potentials in all fields of human endeavour, including the arts, music, sports, science and philosophy, but it has neither exploited them beyond occasional eruptions of creativity nor shown any indication it has the scientific competence to recognise and tackle its challenges in ways that transcend its naturally emotive, violent and short-sighted approach to conflict resolution. ${ }^{2}$

The image of this country has been dragged in the mud as a result of the people's political apathy. Drug and human trafficking, militancy, advanced fee fraud and moral depravity have soiled the image of Nigeria. There is an unprecedented number of Nigerians sentenced to prison or death outside Nigeria for their involvement in criminal activities, immigration crimes, robbery, fraud, smuggling, arms running, prostitution and murder. ${ }^{3}$ Nigeria's ruling class is, with few exceptions, notoriously corrupt and unresponsive to societal problems and needs. ${ }^{4}$ Thus, in every office, there seems to be a desperate drive by Nigerian leaders to corruptly enrich themselves and stash in foreign accounts huge sums of money ${ }^{1}$. Leaders have

${ }^{1}$ Public office holders in Nigeria are notorious for looting the treasury. This fact is well documented by the World Bank, International Monetary Fund, African Union and other anti-graft watchdogs such as the Global Financial turned themselves into sole heirs of public funds and property. Good and adequate healthcare is not without a big price attached to it. The fact that drug and human trafficking, advance fee fraud, anti-social and criminal activities have rocked the country, is now thread-bare. ${ }^{5}$ Many Nigerians have attributed these worrisome behaviours to socioeconomic and political challenges bedeviling the country, including an unstable economy, hunger, unreliable power supply, corruption in high places, poverty, structural unemployment and a dearth of social amenities. As succinctly captured by Fayemi. ${ }^{6}$ The definitive elements of the national moral condition include a raging culture of instant gratification that feeds short termism, profiteering, and fraud. Without making unsustainable generalizations, we can all agree that too many of us are given to cutting corners and trying to attain inordinately disproportionate returns on relatively small investments. We are not as averse to cheating and exploiting our fellow beings as we should be. In fact, it has been argued that our social, civic, political and economic relationships in Nigeria are defined more by mutual predatory exploitation than anything else. We have succumbed to a feverish individualism that prioritizes the desire and gain of the individual no matter how illicitly pursued at the expense of the common good. The sense of communal being that used to be a cardinal feature of public life has been diminished by the rise of an "every person for them" ethos.

Integrity, a US-based group. The GFI, in a report it prepared based on World Bank and IMF data, asserted that $\$ 182$ billion was illicitly taken away from Nigeria and laundered offshore between 2000 and 2009..$^{7}$ Overall, it is estimated that Nigeria has lost over $\$ 400 \mathrm{bn}$ to large-scale corruption since independence in 1960. According to Ndikumana and Boyce, ${ }^{8}$ more than half of the money borrowed by African states, including Nigeria, in recent decades was misdirected within a year, transferred in many cases to private accounts in offshore tax secrecy jurisdictions. 
Nigeria's irreconcilable political elites have left the impression of Nigeria as a nation at war with itself as they endlessly engage in politics of expediency. While the majority of Nigerians reel under the yokes of poverty, disease and misery, the ruling elite has not demonstrated serious commitment, discipline and sacrifice in driving growth and progress. According to, Obiozor. ${ }^{9}$ Nigerian politics and politicians have not developed appreciable level of ethics and moral to distinguish between right and wrong, good and evil in theory and practice. It is therefore, no exaggeration, to say that with the exception of only a few moments of peace, the country's political history since 1966 under military or civilian regimes has been a continuous failure to build a country with political stability, security or sustainable economy. Since then too, the country's constant experience has been that of fear, anger and various levels of political violence. And at the root of all these crises is the tendency and propensity to grab power by one political elite group or another with impunity, lack of tolerance, and lack of sense of kindredship. The decay in the society has reached the point that human life is expendable for material gain. The disturbing aspect of this atrociousness is that it is acceptable. People applaud those who perpetrate evil acts for money. Wealth is idolized irrespective of how it was acquired. The consequence of our depraved attitude towards life has reflected in the demoralized state of the country. Social and political infrastructures have collapsed. Nobody engages in a meaningful agenda with the seriousness of mind to achieve public good. The decline of the common good as an anchor of public morality is coterminous with the ascent of money as the primary indicator of success in our society.

The capacity for conspicuous consumption and reckless financial gratification has become the primary indices of status and accomplishment. According to, Adesina. ${ }^{10}$ "there has been a terrible wave of consciencelessness (sic) over the years, leading to an unprecedented impoverishment of Nigerians, their helplessness in the hands of insurgents who abduct, maim, rape, kill as well as occupy their territory. An epidemic of corruption enveloped the nation, afflicted its leadership recruitment processes, stunted its economic growth, crippled its fighting power and rendered the people hopeless". Many years of colonialism, neo-colonialism and imperialism have fundamentally altered the Nigerian value orientation, belief system, customs and traditions, including our dressing code, food or feeding culture, music, drama, entertainment, language, religion and substituted them with alien ones that constantly contradict and frustrate our development efforts and programmes, thereby giving rise to worrisome paradoxes that have become terrible features of Nigeria. ${ }^{11}$ Thus, ethical transformation and value reorientation have recently become the main focus or issue addressed by governmental agencies, institutions, organizations, individuals and nongovernmental agencies due to the decay in values, ethics and morality in the society. However, as observed by Akinlotan. ${ }^{12}$ Nigerian leaders have not explained why for more than five decades they have taken no step whatsoever in breaking down and remoulding the fundamental underpinnings of their country's existence, and delinking themselves from the (neo-colonial and neo-imperialist) apron strings of their preindependence rulers.

Since the All Progressives Congress (APC) launched the change mantra in the run up to the 2015 general elections in Nigeria, the word, "Change", has become a household name. The change mantra was the magic wand with which the APC defeated the ruling People's Democratic Party (PDP). Nigerians swallowed change hook, line and sinker because of its irresistible attraction. ${ }^{13}$ However, from the March 2015 elections emerged clearly defined national normative and ethical imperatives against historic impediments that have militated against the Nigerian sense of nationhood: ethno-regional and religious affinities. It may be surmised that a clear power transition from a very destructive status quo elite constituency has taken place in favour of a perceived progressive ethical political charge in Nigeria. This is ready to deconstruct the extant political settlement with a view to dismantling the entrenched regime of national governance as well as upending a political culture rooted in an atrociously efficient Nigerian national prebendal order. It is in this connection that, according to Muhammadu Buhari, his mission is to stop corruption and make the ordinary people, the weak and the vulnerable, the new top priority. ${ }^{14}$ This essay examines the President Buhari administration's "change agenda" within the context of the new rebranding campaign and how monotonous such has become in the polity over the years. It attests to the fact that successive occupants of political offices in Nigeria have never been dialectical in thoughts and action, and thus, their campaigns have suffered from the limitations of superficial bourgeois solutions to deeply structural social problems. Elaborating on the theory of ethical and political transformation, this essay seeks to unravel why various national re-orientation and ethical transformation campaigns of successive administrations in Nigeria have not translated into the expected decent political community that appreciates societal values, sensitive to cultural differences, and committed to reducing material inequalities and unethical practices among the populace. With heavy reliance on secondary sources of data, it establishes that pervasive unethical conduct and corrupt practices among the rapacious ruling elites and the amenable mass of the people have continued to dent the image of the country globally.

\section{Ethical transformation and value re-orientation: a conceptual note}

Transformation is a fundamental shift in the deep orientation of a person, an organization, or a society, such that the world is seen in new ways and new actions and results become possible that were impossible prior to the transformation..$^{15}$ It also means the change of the moral character for better through the renewal of the inner-most nature. Pfeiffes (2005) affirms that "national transformation happens when people managing a system focus on creating a new future that has never existed, based on continual learning and new mindset and apply various methods for its actualization". It is a mandate for a radical, structural and fundamental re-arrangement and re-ordering of the building blocks of the nation. It portends a fundamental reappraisal of the basic assumptions that underlie our reforms and developmental efforts that will and should alter the essence and substance of our national life. The expectation of most Nigerians is for a development blueprint that will transform the economy, reinvent the politics of our nation, secure the polity, care for the underprivileged, and provide responsible, responsive and transformative leadership. ${ }^{16}$

Reorientation on its part is the act of changing, adjusting, aligning or re-aligning something, in this case "social values" in a new or different direction. "Values-reorientation" is therefore, is conceptualized as "the act of deliberately attempting to change the direction which attitudes and beliefs in Nigeria are currently oriented or the act of adjusting or aligning behavior, attitude and beliefs of Nigerians in a new or different direction within the public discourse of contemporary Nigerian politics. This is articulated as a move 
away from corruption, embezzlements, dishonesty and general indiscipline to the direction of virtues of honesty, patriotism, hard work, and general abhorrence of social vises". ${ }^{17}$ Values reorientation, as understood by political actors, media practitioners and citizens, is therefore about changing both normative beliefs and practices with regards to behavior within civil society. This public discourse often conflates attitudes and behaviors (beliefs and practices) and articulates a lineal relationship between value change (attitudes and beliefs) and consequent behavior (practice). Kluckhohn. ${ }^{18}$ posits that no society is healthy, creative or strong unless that society has a set of common values that give meaning and purpose to group life. Values are principles, fundamental convictions, ideas, standards or life stances which act as general guides to behaviour or as reference points in decision-making or the evaluation of beliefs or action. ${ }^{19}$ generally, the terms social transformation, social change and revival are used interchangeably to explain the significant alternation of social structures within a social system. The re-orientation of value system is conscious development of human resources through ideological appeals, planning, training, productivity and efficiency in achievements through corporate culture. Value re-orientation could therefore, be defined as the ability to bring back the good values of old back into existence. It could also be the efforts made towards reenacting the good values and the ability to inculcate these values on the individual or members of a society.

\section{Attitudinal change and re-orientation campaign: the realities and gaps}

The need for attitudinal re-orientation had long been recognized as the best way to address the myriad of societal problems confronting the Nigerian society. Consequently, successive administrations have articulated and pursued re-orientation programmes in one form or the other. ${ }^{20}$ Bolarin. ${ }^{21}$ identifies some dominant values which formed the core values upheld by a larger section of the Nigerian society to include the following; detesting laziness, dignity of labour, respect for parent/elders, hospitality, public spiritedness, respect for authority, hard work, respect for sanctity of life, honesty and truthfulness. When these values are grossly compromised, then what you get is greed, corruption, dishonesty, violent crimes, political killings, kidnapping and so many other antisocial behaviours. The various drives for image transformation or re-branding project in Nigeria, in recent time, spring from the different efforts by Nigerians to address the image crisis in the Nigerian state. The re- branding project involves the use of jingles, rallies, mobilisation and articles in national and international media. In spite of the efforts to transform the image of Nigeria for the international community, reports in Nigerian dailies indicate a rise in the rates of criminal activities..$^{22}$ Imaekhai ${ }^{23}$ traced the history of Nigerian ethical revolution from January 15, 1966 when major Kaduna Nzeogwu seized power with the agenda to tackle the ills of tribalism, nepotism, corruption and favouritism. Yakubu Gowon from 1966 to 1975 also accused Aguiyi Ironsi of tribalism, favouritism and nepotism. He had as agenda, reconstruction, rehabilitation and reconciliation to maintain the unity of Nigeria after the thirty months of civil war. However, during Gowon's regime the government became enmeshed in corruption. Nigerians are used to sloganeering. It has never solved any problem. In the agriculture sector, for instance, the country had Operation Feed the Nation, Green Revolution, Back to Land, Directorate of Food, Roads and Rural Infrastructure (DFRRI) etc, but hunger is still at the top of the challenges holding the nation from realizing its potential. ${ }^{24}$ During the Second Republic, the government of President Shehu Shagari proclaimed an "ethical revolution".

The military regime of Major-General Muhammadu Buhari launched the War against Indiscipline (WAI) 32years ago. Mass Mobilisation for Self Reliance, Social Justice, and Economic Recovery (MAMSER) was established by the military administration of President Ibrahim Babangida in the liberal bid to recast the Nigerian political economy. There was also the less remarkable "Not in Our Character" campaign of the regime of the maximum ruler, General Sani Abacha. ${ }^{25}$ These different measures are meant to curb corrupt tendencies in Nigerians, to appeal to their conscience and to correct the negative perception of Nigeria as a corrupt and unreliable nation by the global community, a stigma that has led to a skeptic disposition by the international business community to Nigeria's suitability for business. At the onset of this fourth republic, Olusegun Obasanjo, as President, launched "Heart of Africa" and also formed an elite team tasked with supervising the project implementation, promoting virtues and urging Nigerians to better behaviour. They took the project to the United Kingdom and the United States but neither launch went too well. Obasanjo massively pumped money into the international media to advertise HOA, positioning himself as the Face of Nigeria; just what the world needs to see to come and invest in Nigeria. The programme was eventually dumped after his tenure expired. ${ }^{26}$ Despite the glaring lessons, Nigeria soon embarked on a similar drive with "Rebranding Nigeria" launched by the late Minister of Information and Culture, Prof. Dora Akunyili. Despite armed with a cheap logo and a feelgood slogan, "Good people, Great nation," the project never really took off. Those who conceived it with Akunyili said it was because it never received adequate support by the government but in reality it could not have taken off if Nigerians did not invest in it emotionally. ${ }^{26}$ Akunyili posited that the re-branding project was motivated by the need to find out why some earlier intervention measures to transform Nigeria's image failed and some succeeded but are not sustained. ${ }^{27}$

On his part, the transformation agenda of President Goodluck Jonathan sought to transform the Nigerian people into a catalyst for growth and national development. Under the transformation drive, government was expected to guide Nigerians to build an industrialized modern state that will launch the nation into the first 20 economies of the world by the year 2020. As later witnessed, the transformation agenda brought about a situation in which the government defended and protected corruption to no ends. Indeed, arguably, more than any administration in the history of Nigeria, corruption was more or less the official policy of the state. It was a government that liked to hear the echoes of its panegyrics. It was a government that always played to the gallery and threw money at everything. This was even more noticeable during the 2015 general elections, where raw cash was made available to every Dick, Tom and Harry by the ruling party in a desperate bid to retain political power at all cost. With the ousting of the Jonathan government, Nigerians are confronted again with the latest in vicious cycle of transformation and re-orientation campaigns. While officially launching the current initiative- aimed at educating and enlightening Nigerians to appreciate the values of accountability and integrity- President Muhammadu Buhari. ${ }^{28}$ Affirms that the long-cherished and time honoured, time-tested virtues of honesty, integrity, hard work, punctuality, good neighbourliness, abhorrence of corruption and patriotism, have given way in the main to dishonesty, indolence, unbridled corruption and widespread impunity. He submits further: 
The resultant effect of this derailment in our value system is being felt in the social, political and economic sphere. It is the reason that some youths will take to cultism and brigandage instead of studying hard or engaging in decent living; it is the reason that some elements will break pipelines and other oil facilities, thus robbing the nation of much-needed resources; it is the reason that money belonging to our commonwealth will be brazenly stolen by the same public officials to whom they were entrusted; it is the reason why motorist drive through red traffic lights, it is the reason that many will engage in thuggery and vote-stealing during elections; it is part of what has driven our economy into deep problem out of which we are now working hard to extricate ourselves. Every one of us must have a change from our old ways of doing things, we cannot fold our arms and allow things to continue the old way.

As many commentators, critics and supporters of the re-launched campaign have indicated, the All Progressives Congress (APC) government will not be the first to embark on a campaign to change public attitude to life, governance and public service. And so whether ethical revolution or national orientation, Nigerian governments are skilful in producing slogans and mantras whose conceptual foundations are sometimes amateurish and often war against facts and reality. ${ }^{12}$ Thus, from Babangida's Structural Adjustment Programme (SAP) through Abacha's Vision 2010 to Jonathan's Transformation Agenda, the nation has only moved one step forward and two steps backward. Part of the problems was that the implementers of the reform programmes paid more attention to popularizing their agenda than summoning the sincerity of purpose needed to drive the process. ${ }^{24}$ past campaigns of national mobilisation hardly worked and slogans of national orientation soon became unsustainable. Imaekhai, ${ }^{29}$ observes that each succeeding government in Nigeria promised to eradicate corruption and other social ills and improve on our ethical values but this has been impossible. In 2015 again, the President Muhammadu Buhari-led administration rode to power on a sweeping mandate to give the country a new direction, inject a sense of urgency and purpose into the business of governance. Political analysts believe Nigerians chose the All Progressives Congress (APC) candidate above former President Goodluck Jonathan, because of the perception that as a former military leader, he has the experience and better positioned to tackle Boko Haram insurgency, growing insecurity in the East and the unrest in the Niger Delta region. There was a high expectation that corruption would be tackled head on and policies initiated to create employment opportunities. ${ }^{30}$ The official flag off of the "Change begins with me" campaign brought back memories of the much controversial War against Discipline crusade that marked the high point of Buhari's tenure, as a military dictator between December 1983 and August 1985.

Thirty-three years after, 2016, Buhari tells his country men and women to unite, as one to make Nigeria great once more, by flushing out indiscipline, corruption and other ills that make us not the giant, but almost the laughing stock of Africa. He calls the new campaign: '\#Change Begins with Me. ${ }^{31}$ Buhari, at the launch of the sloganeering campaign, was naturally enthusiastic about it and thus promised to return Nigeria to the path of discipline and truthfulness. To him, a disciplined and truthful people will record far less of the vices that have crippled the country. The new campaign seeks to use persuasive rather than coercive means to achieve attitudinal change in all facets of society. The essence is to emphasise the place of citizens in the attempt to address the decadence of present-day Nigerian society and enthrone the positive change that the country craves. The challenge of a new Nigeria therefore, places a big responsibility on the current administration of President Muhammadu Buhari who inherited an economy that was over the years badly managed and normal standards characteristics of good governance and high moral grounds were obliterated while anti-social patterns of behavior became very pervasive. Nigerians from all works of life, irrespective of ethnic and religious affiliation invested their trust by voting President Buhari to power. That trust was borne out of their sincere and genuine desire to see a new Nigeria where unemployment, corruption, insecurity, violence and other forms of social vices which pervaded the polity will be fought to a standstill. ${ }^{20}$ Suffice it to say that successive leaders, at all levels of government, have been indicted in the court of public opinion for having gone into "service" to empower themselves, families and cronies, while impoverishing the rest of the citizens. ${ }^{32}$

Indeed, it a public knowledge that each change of governmentmilitary and civilian- since 1966 had been justified by the need to fight corruption, except the change of the military dictatorship of Mohammed Buhari, justified by his removers on account of fostering intolerable tyranny. It is, therefore, not illogical to claim that it is not the average citizen that has brought Nigeria to this low ebb; it is those in positions of leadership and the system and style of governance they have pursued, as well as rulers' myopic vision about the eternal power of oil to mask all political, economic, and social problems. Emphasis has been for too long on celebration of power at the hands of those who have it and without regard to the feelings of the average citizen far removed from the corridors of power (Sekoni, 2016:14). The change of leadership and administration via electioneering in 2015 - anchored on the promise "to kill corruption before corruption kills Nigeria"- appeared to be a turning point in the political history of the country. The fight against corruption is the sixth issue in All Progressive Congress' manifesto, which has virtually occupied the attention of the government. That corruption is endemic in Nigeria is not in doubt. That the present government, more than any other past administrations, is committed to fighting corruption is also a common knowledge. As a matter of fact, since the Buhari administration came to power, it has earned the people's confidence with its anti-corruption efforts. The President has seized every opportunity to reiterate his disapproval of the ills that bedevil the nation while warning officials working in his government that he would not tolerate corruption in any form. Nigerians have witnessed in this dispensation criminal charges leveled against professional politicians, amongst who are legislators. With the anti-corruption drive, a number of highly placed government officials, politicians and former officials had been handcuffed and brought to trial to answer corruption charges. Also, a lot of money illegally taken from the public till has been recovered. What Nigerians are skeptical about is an anti-corruption crusade that starts and completes its trials on the pages of newspapers without any fundamental conviction. It is even observed that the Economic and Financial Crimes Commission (EFCC) and the Independent Corrupt Practices Commission (ICPC) "have, instead of fighting corruption, ended up as the actual victims of the fight. The greed and avarice of the political class have added up to continually frustrate the efforts by the two bodies to stamp out corruption from our body politic". Even now, there is growing fear that with the help of clever lawyers, poorly prepared prosecution cases and potentially buyable judges, the culprits might ultimately go free or get light prison sentences. ${ }^{29}$ The 
fundamental question that seems to be agitating peoples' minds is: How can a government impose the virtues of patriotism into people born and bred within a country that has never held up its share of their social contract with them? In his analysis of this seemingly vicious circle of value change mantras in the country, Akinlotan ${ }^{12}$ refers to the Frenchman, Jean-Baptiste Alphonse Kar, who coined a fitting epigram in the 19th century to capture the wastefulness and futility of such idealistic campaigns. Plus ça change, plus c'est la même, he moaned, roughly translated as: 'The more things change, the more they remain the same", it suggests that when change comes at all, it sometimes does so gradually and incrementally, almost imperceptibly.

Yet, whether revolutionary or incremental change, over the centuries and from the experience of many nations, the status quo has yielded only few inches to the most assertive campaigner. On the on-going change-begins-with-you campaign of the Buhari administration, Akinlotan (ibid) submits that: President Buhari merely restated the symptoms of Nigeria's diseased past and present. But the nation ought to have got a gleamer of understanding of what he thinks is really the problem with the national attitude. Had he been able to fairly accurately state the conceptual foundation of the issues that war against the needed new national ethos, Nigerians might be fairly confident that the solution they dream about would not remain the chimera past governments had embraced and choked on for nearly 60 turbulent years. Perhaps, that is why the campaign is seen in many quarters as an afterthought; a calculated diversion from the socioeconomic crises that pervade the country; a mere response to grave political pressures from civil and political society; a conscious attempt at rebranding the seemingly resented regime rather than the nation or more likely that, as Agbese ${ }^{33}$ put it "the government was forced to reach for this straw to mollify public feelings for its inexplicable tardiness in marketing its cardinal objective". With many citizens charging the government with a betrayal of fundamental obligation and poverty of emotional intelligence, this new effort at national mobilization may be an uphill task for the government. The renewal and rejuvenation of national consciousness, according to Alamu ${ }^{34}$ "cannot begin at the deck of the pyramid of fraud. The dominated cannot be made to bear the burden and dereliction of the dominant Hunger and burning resentment do not conduce to rational and respectful citizens. if President Mohammadu Buhari expected the Nigerian populace to show gratitude and admiration of for the new "Change begins with me" campaign, he must have been appalled and dismayed by the fury and ferocity of the return to sender response".

The basic flaw of these efforts at forging national orientation is the mismatch of the objective and subjective factors of change. According to, Komolafe ${ }^{26}$ "you don't change a society by merely moralising (worse still with a tinge of hypocrisy); you have to do something about the social structure". It becomes clear that much of the country's progress and achievements have been beclouded and damaged by the acts and actions of few individuals, corporate organisations and public officers whose activities have wreaked havoc on the reputation of the largest black nation in the world. The problem of image building of a country like Nigeria, just like any other African country, is a very arduous task and must be tackled with utmost caution. What makes news from Africa, including Nigeria in foreign broadcast stations and print media are gory tales of war, hunger, disease, communal clashes and endemic corruption. These and other innate problems have undeniably bedevilled the level of our progress. All these do not augur well for a nation seeking favourable image. However with better leadership now in place, Nigeria must be rebranded to a model which socio-economic cum political modernity and glamour would attract love, dignity and respect rather than disdain, name-calling and disrespect.

For Agbese ${ }^{32}$ therefore, what the country needs is regimentation, not empty sloganeering. Leaders drive regimentation by demonstrating their discipline, their incorruptibility, their obedience to the rule of law, their respect for the rights of others, including and especially the poor. Lack of all these, no doubt, has exacerbated the level of injustice in the country, precipitating self-determination agitations from various militant ethnic groups. Little wonder, that "Nigerians are politically angry, economically hungry and socially militant. Millions of hapless Nigerians are wallowing in abject poverty, existing under primal standards of living. No jobs for teeming youths and graduates. Individual and ethnic interests reign supreme". ${ }^{31}$ This may have informed the pessimism expressed by Adelakun ${ }^{26}$ with regards to the success of the campaign: It is very tempting to relate the many problems of Nigeria to our personal and collective faults; to blame our lack of ethics, and then propound the theory of attitudinal change by telling us that the change will change our circumstances if we gave up parts of ourselves. The truth is, until the immediate concerns of the citizen and the many challenges that confront them are addressed, we may as well be wasting time. The United Nations is an example of how the global order can restructure itself in response to international pressures. But this has not stopped international conflicts as new forces of history come into collision with old forces. ${ }^{35}$ In Nigeria, it is 46 years that the last shot was fired in a tragic civil war with the following slogan from federal side: To Keep Nigeria One is a Task that Must be Done. Today the separatist impulse is prevalent more than ever before in parts of the country. Ethnic and regional champions are fundamentally questioning the structure of the federation. Underlying issues of injustice and underdevelopment have been eclipsed by worsening insecurity in the Niger Delta. So the simple lesson of history is this: mere slogans are not enough to keep a nation united. Material conditions need to be created and structural tasks have to be performed to achieve the desirable goal of unity. ${ }^{25}$ The same point could be made of subsequent campaigns and slogans.

\section{Focus on the real drivers of change and other allied institutions}

Nigeria is passing through difficult times. But, perhaps, more worrying is the fact that the capacity of the government that promised to change the situation is increasingly being called into question. Change was the fulcrum of the All Progressives Congress (APC) and Buhari's message to Nigerians while they were campaigning for the 2015 general election, which they won overwhelmingly. But one year after that victory, Nigerians are almost despairing of seeing any change in the attitudes and circumstances that had caused them to reject the People's Democratic Party government of former President Goodluck Jonathan. ${ }^{36}$ Nigerians have never been in doubt how their country's ills manifest symptomatically. Nor have they ever lacked adequate platitudes to hurl at the combustible follies and foibles that manifest as their country's soft underbelly. What befuddle them, on the contrary, are the conceptual foundations of those ills, and how to engineer the right tools to combat them. Political malfeasance is not Nigeria's exclusive preserve, nor is it the cause of the ills a reorientation programme can affect with platitudinous change. ${ }^{12}$ 
Today, the word, change, has become a cliché in both private and government circles. It is not because it is a new word; it is based on the thinking that, the present time is different from the past times. It is saying that, the way things are being done now is different from the way they were done in the past. As a point of fact, there has to be dedicated pragmatism for change to occur in any situation. It entails making conscious efforts directed at solving problems in practical ways. It means people have to start thinking and acting differently from the way they used to think and act. This is where orientation comes in; because it is believed that for change to occur, good orientation has to be ingrained in the lives of the citizenry. In essence, if the aims of government and individuals are directed towards particular goals changes will occur. It also implies that, for one to move across divides, change must be present. President Buhari is of the view that the derailment in ethical values is connected directly to social crimes of whatever hue, insurgency, economic sabotage and corruption. Perhaps, he is correct, if he were to be looking for immediate causes. But a more critical appraisal of the national derailment he talked about could accommodate far more fundamental reasons beyond issues of ethical disorientation. ${ }^{37}$ According to Sekoni (2016:14), if the new slogan is to have noticeable traction; efforts need to be made to convince citizens that the government is not passing the buck. Nothing changes people's attitude faster than the power of example. In other words, the ball is in the court of the government at every level to right the wrongs of the past and in the process raise the level of morality through examples from those in powers and with access to the nation's resources. All of the persons standing or awaiting trials for corruption, lack of integrity, transparency and accountability so far have been members of the country's elite: top politicians, top military men, top bureaucrats. Since re-branding greatly hinges on changing the psyche of the nation and her people, it requires a multi-sectoral approach to tackle. ${ }^{38}$ This paper focuses on some fundamental areas of our national life like Responsive and Value-Oriented Leadership, Vibrant and Pro-Active Mass Media, Symbiotic State-Citizen Relations, Responsible Family Foundation, Cultural Re-Orientation, Value-Inclined National Policy on Education and Religious Institution for further discussion.

\section{Responsive and value-oriented leadership}

Apart from the real art of governance which, includes among other things, electioneering, stability of democracy, depends on so many variables. In the first place, there is supposed to exist forward and backward linkages between the rulers and the ruled in the socio-political scheme of things. The leadership concern for the followership reduces suspicion on the part of the latter. This in turn spirals into building a more enhanced culture of trust, harmony and peace between and among the political class and the entire citizenry. Severing the relationship between the people while in office means that social contract is no longer respected, and this could lead to unwanted friction in the society. ${ }^{37}$ Transformational leadership is valued centered, sharing of vision, values, respect, and trust, between the leader and followers and achieving unity in diversity. ${ }^{39}$ Human relationists confirmed that the coming together of the values of the leader and the followers is morally acceptable only if it comes from participative decision-making with consensus between leaders and the led.

Ozumba (2014:151) identifies two elements are critical in any effort at ethical re-orientation that are also germane to this paper.
One is leadership and two, is enforceable laws. As rightly noted by Aboluwodi $^{22}$ the effectiveness of the re-branding project in Nigeria rests on leadership rather than rhetoric. Nigerian leaders need to change their value orientation, and understand the essence of governance. They must be able to understand that the central concern of government is how to meet the needs of the people. For the masses, re-branding project begins with the provision of social amenities such as electricity, good schools, drinkable water, good roads, health facilities, and employment opportunities. For, Igbuzor ${ }^{40}$ what is required are good values, correct ideas, appropriate strategies and policies, strategic leadership, good institutions, political will, state capacity and accountable governance. It is believed that leadership will necessarily play a leading role in bringing about the much-needed change. The reorientation must start from the top of governance and leadership as an example for citizens to follow. The campaign for "change", as emphasised in the Vanguard "will fail if the citizenry continue to see a leadership that preaches one thing and does another. Nigerians will ignore the Information Minister, Lai Mohammed and his team of "change" campaigners unless they see a great change in the nepotism and inequities in the selection of people manning sensitive government posts. Nigerians must have a sense of belonging, and only government can provide it. The role of leadership in changing Nigeria for the better cannot be over-emphasised. Once this is done, Nigerians will eagerly key into it". Thus, Nigeria needs a new ethos and a new political culture. To satisfy these needs and to break the mould, new leaders with fiery intellect, deep intuitive grasp of the complex issues shaping the 21 st century, and instinctive feel of the yearnings and aspirations of the people whose disparate needs are sometimes too abstract and formless to put in words, must emerge. The new leaders, detribalised and large-hearted, are the ones to act on the demands of the moment. They are the ones to drive the great processes needed to tackle the present challenges as well as brilliantly anticipate the future challenges still embedded in the womb of time. ${ }^{12}$

\section{Vibrant and pro-Active mass media}

According to Voelker, ${ }^{42}$ the mass media are important forces in our society. They provide information and entertainment and, at the same time, have persuasive powers that are capable of effecting radical changes. ${ }^{43}$ observes that the mass media are effective tools for creating linkages between the society and the type of sociopolitical ideology- whether democracy, autocracy or socialism- that is in operation. In rebranding Nigeria, the mass media is expected to ensure objective reportage of issues, avoiding sensationalism; bearing in mind that false reportage undermines the democratic experience. The entertainment and art industries are expected to produce art that showcases the exciting mix of Nigeria's cultural diversity and the very values that hold the African society together. ${ }^{3}$ Cultural, moral and community opinions have been changed largely by the fact that the mass media can provide seemingly uninterrupted news that has influenced community life, indigenous culture and morals as well. The Nigerian media over the years has demonstrated its capacity to galvanize public opinion and engender public discourse among Nigerians. Nigerian media has continued to play significant role in the overall development of the nation. The media can also play a very important role in elevating issues to the systemic agenda and increasing their chances of receiving consideration on institutional agendas. However, since the achievement of the change agenda and ethical transformation depends essentially on the government's ability 
to integrate and coordinate policy making and implementation across the public sector, as well as the social, economic and environmental policy portfolios, all the relevant public and private institutions should be actively involved in the mobilization, public education and orientation.

\section{Symbiotic state-citizen relations}

Nigeria, according to ${ }^{44}$ needs to create a social contract between the state and its citizens. This involves, primarily, the obligations of citizens (such as paying taxes) in exchange for the protection of life and limb, civil liberties and its limits, as well as the sustainable provision of basic infrastructure and social safety nets by the state. This gives citizens a sense of belonging, with mutual accountabilities between the government and the governed. For, Komolafe ${ }^{25}$ it is the responsibility of government to create the conditions for socio-economic actors to operate in their legitimate quest to meet their needs. Change cannot begin with a people with increasingly limited access to basic needs such as food, water, healthcare, basic education and decent housing. The leadership preaching change would rather find a better audience in a people that could take basic needs for granted. When citizens see public servants, politicians and senior government officials abusing national laws and getting away untouched, they get the message it is alright to perpetrate crimes against the society. ${ }^{45}$ Crime and other social vices multiply when the people are suffering. But someone who is comfortable is less prone to crime. Nigerians in the developed countries are more law-abiding than Nigerians at home simply because they are more comfortable than those at home. It is counterproductive to demand fundamental attitudinal change from a mass of hungry, unemployed and dejected population. ${ }^{13}$ The point is that, the psychological impact of a failing state on the behaviour of citizens is so strong it can create dissonance in a time of reorientation. That is why many do not want to hear about the change Mr. President is talking about. ${ }^{35}$ Thus, there is the need for a radical development strategy that guarantees inclusiveness as opposed to exclusiveness in governance and that is people-driven from conception to implementation. This development strategy must be sustainable with the genuine desire to end poverty, provide productive employment, and satisfy basic needs of all categories of citizens and fair sharing of surplus value. Fortunately, the nation's democratic experiment provides political platform to meaningfully engage the citizens because representative democracy creates an opportunity for groups and individuals to have a voice in government, even though they cannot participate directly in government. However, the mere existence of representative institutions is not enough for meaningful democracy. The real challenge is to forge a link between a society's numerous and diverse policy preferences and the representatives who govern. This link requires some entity to mediate between citizens and state institutions.

\section{Responsible family foundation}

Throughout history, strong families have helped to make strong societies. The family therefore remains the best arrangement for bringing the children to be mature and credible adults. The family is the first social contact the child has and his experience in the process of development matters a lot because such early experiences are hard to erase. The onus still lies on the president to re-invent the wheel and realize that the greatest resource for national development is human resource. Attitude can be taught, once learnt, they are difficult to change. ${ }^{20}$ The family's affective role of nurturing and supporting its individual members includes promoting and safeguarding the health of children as well as instilling moral and social values in them, with the overall goal being to ensure that the next generation is productive and socially responsible. ${ }^{46,47}$ Among the social factors that affect individual people in particular are social groups with which a person comes into contact. The most important social group to influence individual's development, however, is the family. Functioning family environment has in the process of socialization of the individual irreplaceable importance. During socialization one becomes a cultural and social being who acts according to recognized rules directed their behavior towards socially accepted value and meet individually modified roles and expectations. Family provides initial human behavior patterns in an orientation and initial interpersonal relationships. According to Archbishop, ${ }^{48}$ "if the family is dysfunctional, society and nation will also be dysfunctional... any country that wants to build its capacity for development must start with the family. The family is the first place where children are taught values such as honesty, hard work, trust in God, love of neighbour and society"

\section{Cultural re-orientation}

Others, like Ayakoroma, ${ }^{49}$ have also advocated for "cultural re-orientation" considered to be capable of creating a process of positive impact on national development. The strategies of national development would thus depend on the understanding of the culture, the adaptation of its elements for political, educational and economic development, as well as its strengths for social integration and development. According to him, if the Federal Government of Nigeria under the leadership of President Muhammadu Buhari makes culture the centre-piece of its national orientation, the country stands to benefit economically, socially, politically and otherwise. The question is: What then is the caveat? The advice has always been for us to go back to our roots; to our core values system. This is a situation where the citizenry imbibe Nigerian, nay African, culture which encapsulates genuine love for people and the country, knowledge of Nigerian indigenous languages, promoting Nigerian dress culture, respect for elders and constituted authority, hard work, honesty, fear of God, integrity, humility, craftsmanship, accountability, transparency, being our brothers' keepers, just to mention few. Unarguably, these are attributes that can be used, maximally, for the development of the nation. In his analysis, Obiozor ${ }^{9}$ contends that the Change Agenda should now, while redefining our national priorities, emphasise ethics and morals: As a nation, Nigeria should adopt the principle of "applied ethics" in all aspects of our national endeavours, from politics to economics, culture to sports, etc.

Applied ethics attempts to apply ethical and moral theories to real life situation; and, as a discipline has been successfully utilised by several countries from China to Malaysia. Indeed, it was labour ethics and morals through the strategic discipline they inculcated on the citizens that gave rise to the "Asian Tigers." Thus, applied ethics which is used in some aspects of determining public policy as well as by individuals facing difficult decisions, will be a useful instrument for implementing the 'Change Agenda' of the Buhari administration. It is a fact that culture can be found in Nigeria's political institutions, ancient traditions, literature, languages and even in moral values. The moral value of a particular group of people is an embodiment of their culture. There are many cultural agencies and institutions that are entrusted with the enormous responsibilities of sustaining, packaging, 
promoting, marketing and protecting Nigeria's cultural heritage. In achieving these goals, the various cultural agencies have to partner with the media for proper packaging, dissemination, orientation, education, propagation and marketing of the 'Change Agenda'.

\section{Value-inclined national policy on education}

Education is a crucial sector in any nation. Being a major investment in human capital development, it plays a critical role in long-term productivity and growth at both micro and macro levels. According to $\mathrm{UNESCO}^{50}$ "education refers to the total process of developing human ability and behaviours". It is an organized and sustained instruction designed to communicate a combination of knowledge, skills and understanding value for all activities of life. Education and society are inseparable. Society equips education with the values to be transmitted while education exposes each generation of young people to the existing beliefs, norms and values of their culture. ${ }^{51}$ Fafunwa ${ }^{52}$ defines education as what each generation gives to its younger ones which makes them develop attitudes, abilities, skills and other behaviours which are the positive values to the society in which they live. As a matter of fact, education develops in individuals those values which make for good citizenship, such as honesty, selflessness, tolerance, dedication, hard-work and personal integrity, all of which provide the rich soil from which good leadership potential is groomed. The National Policy on Education (NPE), ${ }^{53}$ also specified values system acceptable in the country. This should therefore, be inculcated in the learners through the quality of educational instructions. These include moral/spiritual values, dignity of human person, self-reliance and communal responsibility, amongst other; It particularly tasks tertiary institutions to "develop and inculcate proper values" implying that there are improper or negative values that should be nipped in the bud. As earlier indicated, transformation can also be social when talking about the improvements that have taken place in the realm of the way of life of a people, their social etiquettes, their modes of dressing, food types and the like. It is individuals who have been positively transformed who can transform the society. It is from this perspective that it can conveniently be argued that education can transform a society.

\section{Religious institution and moral teachings}

The religious beliefs, values, and practices held by the mainstream in a society are an expression of their basic worldview, a manifestation of assumptions about what exists outside the narrow confines of everyday experience. In most societies, religious leaders provide guidance on interpreting these beliefs and traditions and articulate the appropriate values and correct moral behaviour for living in alignment with these beliefs. ${ }^{54}$ Religious institution- a place where people seek solace and show penitence- should therefore, preach the right values missing in the society. Religious leaders should place less emphasis on materials things and focus more on teaching their followers how to live an impactful life. Religion has rules about conduct that guide life within a social group and it is often organised and practised in a community, instead of being an individual or personal affair. All African societies view life as one big whole and religion permeates all aspects of life. Mbiti ${ }^{55}$ asserts that Africans are notoriously religious. According to him, religion permeates all departments of life to such an extent that it is not easy or possible to isolate it. Although the African religious consciousness was initially derived from the practice of traditional religion, Christianity and Islam have given further impetus to this consciousness. Conversely, however, as the unfolding of a natural cultural process, both Christianity and Islam have in turn been influenced by traditional religion. ${ }^{56}$ Religion plays an indispensable role in fostering values such as honesty, integrity, openness, forthrightness and tolerance. ${ }^{57}$ Such values are crucial for the development of good economic and democratic political systems. Religious leaders and traditional rulers are thus, expected to inculcate moral education in their various programmes and extol the spirit of service and excellence in their congregations and subjects respectively.

\section{Conclusion}

It is argued in this essay that one of the most daunting problems which have stunted the growth of Nigeria democratically and advance its stability is the lack of adherence to ethos, rule of law and constitutionality. Curiously, it is universally agreed that Nigeria's woes are self-inflicted and, therefore, substantially amenable to functional solutions. Successive occupants of political offices in Nigeria have never been dialectical in thoughts and action. Hence their campaigns have suffered from the limitations of superficial bourgeois solutions to deeply structural social problems. The nation's socio-political history is replete with campaigns, slogans and rhetoric of change to better ways. In other words, and as established in this essay, Nigerians are used to sloganeering. But, it has never solved any problem. However, it is widely admitted by both Nigerians and foreign actors alike that the Buhari administration's choice of anti-Corruption as one of its cardinal agenda is a timely important decision to confront an issue that has dented the image of the country and its citizens worldwide. While it is admitted that it is only individuals who have been positively transformed who can transform the society, there is the need for a radical development strategy that guarantees inclusiveness as opposed to exclusiveness in governance and that is people-driven from conception to implementation. This development strategy must be sustainable with the genuine desire to end poverty, provide productive employment, and satisfy basic needs of all categories of citizens and fair sharing of surplus value. Lastly, the role of leadership in changing Nigeria for the better cannot be over-emphasised. ${ }^{58}$

\section{Acknowledgment}

None.

\section{Conflict of interest}

None.

\section{References}

1. Kalu, Orji Uzor. Challenges of democratic governance in Nigeria (1). The Sun. 2016.

2. Akinlotan Idowu. Future more Uncertain than the Troubled Past. The Nation publishers. 2016.

3. Umeh Jennifer. How to rebrand Nigeria. The Nation. 2015.

4. Khakee Anna. EU Democracy Promotion in Nigeria: Between Realpolitik and Idealism. FRIDE's Working Papers. 2007;47:1-28.

5. Fabamise, Olajide. Can Buhari Rebrand Nigeria? Brands mart. 2015

6. Fayemi Kayode. Crisis of Values: Reclaiming our Society. Women in Management, Business and Public Service (WIMBIZ) Thursday. 2016.

7. Whistle-blowing in Nigeria's Anti-graft Crusade. The Punch. 2017

8. Falana Femi. Ethics and Governance, the Rule of Law and AntiCorruption: A Nigerian Dilemma. Sahara Reporters. 2007. 
9. Obiozor George. Moral, ethical imperatives of Nigeria's change agenda (2). The Guardian. 2015.

10. Adesina Debo. Failure of Kindness, Failure to Rescue. The Guardian. 2016.

11. Nwekeaku Charlie. The Challenges of Cultural Agencies and Mass Media in Promoting The Transformation Agenda in Nigeria. International Journal of Asian Social Science. 2014;4(3):422-433.

12. Akinlotan Idowu. Plus ça change. The Nation. 2016.

13. Onyekakeyah Luke. Thoughts on Change. The Guardian. 2016.

14. Araoye Ademola. Normative and Ethical Imperatives of Change in Nigeria's Democratic Consolidation. The Thinker. 2015;66:1-28.

15. Asobie A. Challenges of Governance: Need for Transformational Leadership, Presented at National Conference of ANAN. International Journal of Politics and Good Governance. 2012;7(1):1-38.

16. Osisioma Benjamin. Nigeria's Transformation Agenda: The Management and Leadership Challenges. Paper Presented on the Occasion. 2012;68(24):1-5.

17. Okafor GO. The Nigerian Mass Media and Reorientation of Values: Problems and Prospects. American Journal of Social Science. 2014;2(2):21-28

18. Omoegun OM, Longe OO, Ahimie, B et al. Effecting Values ReOrientation among Primary School Children through Story Telling. Journal of Social Sciences. 2009;19(1):63-69.

19. Halstead J, Taylor M. Values in Education and Education in Values. Falmer Press. UK;1996.

20. Agu Fidel. Urgent Need for Value Re Orientation. Leadership. 2016.

21. Bolarin TA. Values disorientation in the Nigerian System, in Ivowi, U.M.O. ed. Education for value, Lagos, The CIBN Press Limited. 2005.

22. Aboluwodi Akinjide. Nigeria's Image Crisis and Lessons from Obafem Awolowo's Leadership and Education Ideologies. Journal of Education and Human Development. 2014;3(2):527-540.

23. Saale, Lazarus Baribiae. Prayer and Social Transformation in Nigeria: A Christian Perspective, African Research Review. An International Multidisciplinary Journal. 2014;8(4):111-121.

24. Mahmood Abba. Diversification: An Agenda for Buhari. Leadership. 2016.

25. Komolafe Kayode. On the Origins of Change. This Day. 2016.

26. Adelakun Abimbola. Dear Lai, Change does NOT begin with me. The Punch newspaper. 2016.

27. Adelakun Abimbola. Relaunch of WAI: Buhari Plays His Last Hand Naija Headlines. 2016.

28. Buhari Muhammadu. Full Text Of PMB's Speech At The Launch Of Change Begins With Me. Leadership. 2016.

29. Imaekhai FJ. The Nigeria society and Ethical Revolution. Isiramen FJ Imaekhai, BO Igboin, editor. Religion and the Nigerian nation: Some topical issues. Ibadan:En-Joy Press and Books;2010.

30. Mordi Raymond. Buhari: Beyond the 'Change' mantra. The Nation. 2016

31. Osagie Eric. Nigeria: The challenge of change. The sun. 2016

32. Ukwu Daniel. Posterity and Buhari's Fight with Corruption. The Guardian. 2016.

33. Agbese Dan. Na slogan we go chop? The Guardian. 2016.
34. Alamu Tatalo. The Nation in Question: Some Conceptual Clarifications. The Nation. 2016.

35. Obia Vincent. The Change Begins With Me Campaign. This Day. 2016

36. Williams Alab. To Communicate Real Change. The Guardian. 2016.

37. Alyebo NO. The Re-branding Nigeria Project: The Sociolinguistic Imperatives of Nigerian Indigenous Languages. Journal of Igbo Language \& Linguistic. 2012;5:104-111.

38. Erunke, Canice. Consolidating Democratic Governance in Nigeria: Analysis and Suggestions. African Journal of Social Sciences. 2012;2(2):67-73.

39. Carey MR. Transformational Leadership and the Fundamental Option for Self-Transcendance. Leadership Quarterly. 1992; 3(3):217-236.

40. Igbuzor O. Value Re-orientation and Transformation: A Panacea for Growth and Development. A Paper Presented at the Institute of Strategic Management. 2013.

41. Buhari's Change begins with me. Vanguard Editorial. 2016.

42. Voelker FH. Mass Media: Forces in Our Society. Atlanta: Harcourt Brace Jovanovich. 1975:1-422.

43. Akinfele R. Nigerian Mass Media and National Crises. Nigerian Press Council publication. 1995.

44. Moghalu Kingsley. The Path to Inclusive Growth. This Day. 2016.

45. Obijiofor Levi. When Citizens no Longer Believe in Change. The Sun. 2016.

46. Perrino T, Gonzalez S.A, Pantin H, et al. The role of families in adolescent HIV prevention: A review. Clin Child Fam Psychol Rev. 2000;3(2):81-96.

47. Peterson R. Families first: Keys to successful family functioning. $V C E$ Publications. 2009: 350

48. Nigeria: Family as Agent of Mercy and Harmony. Vatican Radio. 2016.

49. Ayakoroma, Barclays Foubiri. National Orientation as a Catalyst for Change: Thoughts on Some Cultural Imperatives. 2015.

50. Nigerian Human Resource Development and civilization: Education and World Affairs. UNESCO. UK;2000:1-288.

51. Schacfer RL. Sociology: A brief introduction. McGraw Hill. 2000;USA.

52. Fafunwa AB. History of Education in Nigeria. Ibadan: NPS Educational Science and education. 1974;1(1):11-15.

53. National Policy on Education. Federal Republic of Nigeria. NERDC Press. 2004:1-34.

54. Tools for Peace? The Role of Religion in Conflicts. Report from an International Inter-Religious Peace Conference 21-24 November. 2004;1-34.

55. Heinemann, Mbiti JS. African Religions and Philosophy. $2^{\text {nd }}$ ed. Nigeria;1999.

56. Muzorewa GH. The Origins and Development of African Theology. Published by Orbis Books, Maryknol. 1985.

57. Tsele M. The Role of the Christian Faith in Development. In: Belshaw D, Calderisi R, Sugden C, editors. Faith in Development: Partnership between the World Bank and the Churches of Africa, 203-218. Oxford, Regnum. 2011;1(1):262

58. Rapheal, Ojo Joseph. Religion, National Transformation and the Nigerian Society: Some Reflections. International Journal of Gender and Women's Studies. 2014;2(2):117-136. 